\title{
Estimation of a longan stink bug, Tessaratoma papillosa in Son La Province, Vietnam
}

\author{
Uớc tính trũ lượng loài bo xít nhãn (Tessaratoma papillosa) ở tỉnh Sơn La, Việt \\ Nam \\ Research article
}

Pham, Mai Quynh*

Institute of Ecology and Biological Resources, Vietnam Academy of Science and Technology, 18 Hoang Quoc Viet, Ha Noi, Vietnam

\begin{abstract}
Many insects are considered as potential sources of food for humans because of their high content of protein, fat, minerals and vitamins. Tessaratoma papillosa Drury, a stink bug of longan tree has long been consumed by many people in Vietnam as a supplemental source of nutrition. This insect is one of the most severe pests of longan tree. The use of this insect as supplementary nutrient could actively reduce the pests on longans, contributing to increase productivity and quality of longan fruit. The aim of this paper is to estimate the volume of mature and young Tessaratoma papillosa on longan trees in Son La Province, Vietnam.
\end{abstract}

\begin{abstract}
Nhiều loài côn trùng được coi là nguồn thực phẩm tiềm năng của con người vì chúng có chứa hàm luợng cao protein, chất béo, chất khoáng và vitamin. Loài bo xít nhãn Tessaratoma papillosa Drury, tù lâu đã được nhiều người dân ở Việt Nam sủ dụng nhu là một nguồn thực phẩm bổ sung dinh duõng. Loài bo xít nhãn là một trong nhũng loài gây hại nghiêm trọng nhất đối với cây nhãn. Việc sử dụng loài côn trùng này không những bổ sung chất dinh dữong cho con người mà còn góp phần chủ động giảm loài sâu hại trên nhãn, góp phần tăng năng suất và chất luợng trái cây nhãn. Mục đích của bài viết này là để uớc tính khối luợng trương thành và ấu trùng loài Tessaratoma papillosa trên cây nhãn ở tỉnh Sơn La, Việt Nam.
\end{abstract}

Keywords: edible insects, longan tree, stink bug- Tessaratoma papillosa, Son La, Vietnam

\section{Introduction}

A varieties of insect species has been exploited for food by local people in northern Vietnam $[3,9,11,12,16]$. Research to use insects as a supplement food for humans in the future is considered to be really necessary along with the explosive increase of human population $[1,2,4,5]$. Longan tree Dimocarpus longan is the most valuable fruit tree in Son La province. The area of longan planted in the whole province is approximately 10,501 ha in 2013 , of which 9,860 ha has been harvested [19, 20,21]. Fresh and processed longan products of Son La, especially in the Song Ma District, are now known well and gradually dominate its market in the provinces of North Vietnam, where local people likes this fruit. In this area, people also commonly consume longan stink bug, Tessaratoma papillossa as the supplementary nutrient. The longan stink bug, $T$. papillossa, is one of the most harmful pest of the longan tree. This stink bug insert its tentacle into buds, stem and unripe berries of the longan to take the food, resulting in buds and flowers withered, fruit falling and rotten. It impacts on the yield and quality of the fruit.

Mature longan stink bugs collected at the study sites are 25 $-30 \mathrm{~mm}$ in length, and are golden brown in color. The lower part of the body is covered with white wax-like substance. Adult longan stink bugs live over the winter in the dense foliage. The longan trees start flowering when the weather turned warmer, normally in late March or early April, and this is the time for adult longan stink bugs to start mating and laying eggs. The eggs are nested by a group of 12-14 attaching to the lower face of the longan leaves. Freshly laied eggs are nearly round shape, light green in color and easy to find by naked eyes. The eggs then turn dark pink, followed by dark grey in color before hatching. Eggs of longan stink bug were laid boomingly around mid-April. The freshly hatched larvae are usually bright yellow, then changing to purple gray. Nymphs live together for few hours, then began dispersing to looking for the food. Nymphs are comprised of 5-age stages. At the 
first age nymphs are $5 \mathrm{~mm}$ in length and reach 18-20 $\mathrm{mm}$ when they are 5 th age stage. Adult and nymphs defends themselves from severe condition like hard impact, or hot sunlight by thanatosis. They desperately fall to the ground, secrete stinky, lie motionless, but awake to climb up the tree when sense safe.

Both adults and nymph of the longan stink bugs are harmful to the longan trees at the budding and flowering stages. They use their tentacle into buds, stem and unripe berries resulting in losing bud, flower and fruit loss. They greatly affect the tree growth, production and quality longans.

The local people, including Kinh, Thai, Muong in many places in Son La have a knowledge and tradition of consuming the longan stink bug as a favorite dish $[3,6,8,10$, $14,15,17,18]$. The exploitation and utilization of $T$. papillossa as food is one of the method to reduce the number of pests for longan, contributing to a better crop yield [7].

Provide additional materials on the status of the longan stink bug in Son La province (number of adults and nymphs on the longan tree in different locations, with the different age and size...) and the estimated quantity of matures and nymphs of the longan stink bug which can be harvested for food in the study locations.

\section{Subjects, activities, study sites and methods of study}

\subsection{The aim of this study}

- Clarify the current status of the longan population grown in Son La province (the total number of trees, harvestable trees...).

- Inspect the current status of the longan stink bug Tessaratoma papillossa (number of adults and nymphs in the different study sites, as well as tree ages...) and estimated number of the longan stink bugs, which are harvestable for food in the study area.

- Study the pest characteristics of the longan stink bug of the longan trees in Son La province.

- Study the custom of exploitation and processing of the longan stink bug for food by the locals.

\subsection{Study localities}

We selected one commune per district to carry out the research. In Sop Cop District, longan planted area is only about 110 ha, which is considerably small area compared to that of other districts, Thus, we do not include Sop Cop District in the study areas. The communes selected for this study are: Chieng Sinh (Son La City), Ta Xua (Bac Yen District), Gia Phu (Phu Yen District), Chieng Khuong (Song Ma District), Muong Lum (Yen Chau District), Chieng Son (Moc Chau District), Chieng La (Thuan Chau District), Ta Bu commune (Muong La District), Muong
Chien (Quynh Nhai District), Hat Lot town (Mai Son District).

\subsection{Methods}

- The data of the study areas and the status of the longan population at the study sites in Son La province were obtained either by direct field survey, questionnaire interview or refer the Statistical Yearbook 2013 Son La (Son La People Committee).

- Status, quantity and pest characteristics of the longan stink bug on longan trees were obtained by direct field survey using following techniques:

+ At each study site, we selected 5 each of longan trees of different maturation stages; 1) not yet harvested, 2) harvested for 1-3 years, 3) harvested 4-6 years, and 4) harvested for over 6 years.

+ At the beginning of March, when the weather turned to warm, we started tracking the emergence of mature longan stink bugs, and inspected the presence of eggs and nymphs on the leaves.

+ Mature longan stink bug and nymphs on individual longan tree were collected in May using a net racket fitted on a bamboo pole-handle of about $3 \mathrm{~m}$ length. At least two people were involved in collecting the bugs. To start with, area around a longan tree was covered with canvas cloth, and one person placed the net racket over the flower or fruit clusters and gently shake the racket to collect the mature bugs and the nymph. The second person used forceps to catch the insects dropped down on the canvas cloth. After collecting all insects on the flowers and the fruits, the first person strongly shake the branches of the tree to make sure all insects left on the tree will fall down on the canvas cloth.

After measuring the total weight of longan stink bugs, $T$. papillosa, on one Longan tree, it was multiplied by the total of longan trees in each study site to calculate the estimated total amount of the bugs across the Son La Province.

- The information and data on exploitation, processing and trade of the longan stink bug at the study sites was collected through the interviews and questionnaire survey for the local people.

- The collected data were analyzed using biostatistic methods.

\section{Results and Discussion}

\subsection{Current status of the longan population in Son La Province}

The longan planted area and the number of trees in Son La Province are shown in Table 1.

Table 1. Longan-planted areas and the number of longan trees in Son La Province

$\mathrm{N}_{0} \quad$ Districts $\quad$ Area (ha)




\begin{tabular}{|c|c|c|c|c|c|c|}
\hline & & Total & Harvested & Total & Harvested & Not yet Harvested \\
\hline 1 & TP Són La & 578 & 578 & 11,560 & 11,560 & 0 \\
\hline 2 & Quynh Nhai & 348 & 177 & 69,600 & 35,400 & 34,200 \\
\hline 3 & Thuan Chau & 216 & 189 & 43,200 & 37,800 & 5,400 \\
\hline 4 & Muong La & 736 & 700 & 147,200 & 140,000 & 7,200 \\
\hline 5 & Bac Yen & 512 & 333 & 102,400 & 66,600 & 35,800 \\
\hline 6 & Phu Yen & 1,053 & 892 & 210,600 & 178,400 & 32,200 \\
\hline 7 & Moc Chau & 326 & 321 & 65,200 & 64,200 & 1,000 \\
\hline 8 & Yen Chau & 510 & 496 & 102,000 & 99,200 & 2,800 \\
\hline 9 & Mai Son & 1,315 & 1,315 & 263,000 & 263,000 & 0 \\
\hline 10 & Song Ma & 4,796 & 4,750 & 959,000 & 950,000 & 9,000 \\
\hline 11 & Sop Cop & 111 & 109 & 22,200 & 21,800 & 400 \\
\hline & Total & 10,501 & 9,860 & $1,995,960$ & 1867,960 & 128,000 \\
\hline
\end{tabular}

Survey data of the longan gardens in some areas in Song Ma District, Mai Son District, Phu Yen, Muong La District, Son La City showed that approx. 200 longans were planted per ha, corresponding to 7 by $7 \mathrm{~m}$ per tree. Among all study areas in Son La Province, Song Ma District has the largest area (4,796 ha) of longan gardens and the number of longan trees planted was 959,000 trees. Followings are Mai Son District (1,315 ha), Phu Yen (1,053 ha), Muong La (736 ha) and Sop Cop (111 ha). The total area of longan planted in Son La is 10,501 ha, with approximately 2,100,200 longan trees. 1,872,000 longan trees are harvestable producing the total of 47,976 tons of longan fruit in 2013.

\subsection{Characteristics of longan stink bug, Tessa- ratoma papillossa}

Mature longan stink bugs collected at the study sites are 25 $-30 \mathrm{~mm}$ in length, and are golden brown in color. The lower part of the body is covered with white wax-like substance. Adult longan stink bugs live over the winter in the dense foliage. The longan trees start flowering when the weather turned warmer, normally in late March or early April, and this is the time for adult longan stink bugs to start mating and laying eggs. The eggs are nested by a group of $12-14$ attaching to the lower face of the longan leaves. Freshly laied eggs are nearly round shape, light green in color and easy to find by naked eyes. The eggs then turn dark pink, followed by dark grey in color before hatching. Eggs of longan stink bug were laid boomingly around mid-April. The freshly hatched larvae are usually bright yellow, then changing to purple gray. Nymphs live together for few hours, then began dispersing to looking for the food. Nymphs are comprised of 5-age stages. At the first age nymphs are $5 \mathrm{~mm}$ in length and reach $18-20 \mathrm{~mm}$ when they are 5th age stage. Adult and nymphs defends themselves from severe condition like hard impact, or hot sunlight by thanatosis. They desperately fall to the ground, secrete stinky, lie motionless, but awake to climb up the tree when sense safe.

Both adults and nymph of the longan stink bugs are harmful to the longan trees at the budding and flowering stages. They use their tentacle to inject toxic substance into buds, stem and unripe berries resulting in losing bud, flower and fruit loss. They greatly affect on tree growth, production and quality longans.

\subsection{Longan stink bug population and estima- tion of the production in the study sites}

The amount of the longan stink bugs at different stages of longan trees in each study sites are presented in Table 2.

Table 2. The amount of longan stink bugs obtained in the study sites

\begin{tabular}{lllll}
\multicolumn{1}{c}{ Study sites } & $\begin{array}{c}\text { Immature } \\
\text { tree (gr/tree) }\end{array}$ & $\begin{array}{l}\text { Tree harvested for } \\
\mathbf{1 - 3} \text { years (gr/tree) }\end{array}$ & $\begin{array}{l}\text { Tree harvested for } \\
\text { 4-6 years (gr/tree) }\end{array}$ & $\begin{array}{c}\text { Tree harvested for over } \\
\text { 6 years (gr/tree) }\end{array}$ \\
\hline Chieng Sinh (TP Sơn La) & 0 & $4.2 \pm 0$ & $8.75 \pm 1.38$ & $9.55 \pm 1.25$ \\
Muong Chien (Quynh Nhai) & $0.67 \pm 0.1$ & $5.55 \pm 1.35$ & $8.15 \pm 1.21$ & $9.50 \pm 2.26$ \\
Chieng La (Thuan Chau) & $0.57 \pm 0.1$ & $4.5 \pm 1.28$ & $7.55 \pm 1.27$ & $8.25 \pm 1.32$ \\
Ta Bu (Muong La) & $0.62 \pm 0.1$ & $5.1 \pm 1.33$ & $7.25 \pm 1.33$ & $7.75 \pm 1.19$ \\
Ta Xua (Bac Yen) & $0.62 \pm 0.1$ & $3.75 \pm 0.57$ & $6.25 \pm 0.65$ & $11.00 \pm 2.31$ \\
Gia Phu (Phu Yen) & $0.80 \pm 0.1$ & $8.2 \pm 1.05$ & $10.05 \pm 1.41$ & $13.75 \pm 2.37$ \\
Chieng Son (Moc Chau) & $0.62 \pm 0.1$ & $3.55 \pm 1.30$ & $6.75 \pm 0.92$ & $8.35 \pm 0.83$ \\
Muong Lum (Yen Châu) & $0.67 \pm 0.2$ & $3.15 \pm 1.33$ & $5.00 \pm 0.33$ & $8.50 \pm 1.49$ \\
Hat Lot (Mai Son) & 0 & $8.55 \pm 1.40$ & $10.2 \pm 1.29$ & $12.5 \pm 1.25$ \\
Chieng Khuong (song Ma) & $0.95 \pm 0.2$ & $9.1 \pm 1.38$ & $11.5 \pm 1.45$ & $13.95 \pm 3.38$ \\
Sop Cop (Sop Cop) & $0.55 \pm 0.1$ & $3.45 \pm 1.2$ & $5.15 \pm 1.28$ & $6.75 \pm 1.8$
\end{tabular}

As can be seen in Table 2, the amount of longan stink bugs per tree are higher in the areas that have large and concentrated longan trees, e.g., Gia Phu (Phu Yen district), Hat Lot (Mai Son district), Chieng Khuong (Song Ma district).
In these areas, the production of longan stink bugs. Thus the longan flower is assumed to be an important factor to attract longan stink bug to live and lay eggs. 
The data in Table 2 is the basis to estimate the production of longan stink bugs in each site and in the whole province. However, because we do not have accurate data on the proportion of the maturation stages of longan trees in the whole province, we made estimation of the amount of longan stink bugs per non-harvested and harvested tree in the study sites. The results are shown in Table 3.

Table 3. Average weight of longan stink bugs obtained per non-harvested and harvested longan trees in the districts in Son La province

\begin{tabular}{clll}
$\mathbf{N}_{\mathbf{0}}$ & Districs & None-harveted longans $(\mathbf{g})$ & Harveted longans $(\mathbf{g})$ \\
\hline $\mathbf{1}$ & TP Son La & 0 & 7.5 \\
$\mathbf{2}$ & Quynh Nhai & 0.675 & 7.73 \\
$\mathbf{3}$ & Thuan Chau & 0.575 & 6.76 \\
$\mathbf{4}$ & Muong La & 0.625 & 6.37 \\
$\mathbf{5}$ & Bac Yen & 0.625 & 7.0 \\
$\mathbf{6}$ & Phu Yen & 0.800 & 10.67 \\
$\mathbf{7}$ & Moc Chau & 0.625 & 6.22 \\
$\mathbf{8}$ & Yen Chau & 0.675 & 5.55 \\
$\mathbf{9}$ & Mai Son & 0 & 10.42 \\
$\mathbf{1 0}$ & Song Ma & 0.950 & 11.52 \\
$\mathbf{1 1}$ & Sop Cop & 0.55 & 5.12
\end{tabular}

Thus the production of longan stink bugs for particular district could be estimated based on the given data in Table 2 and Table 3 .

To analyse the production pattern of longan stink bugs, we calculated the proportion of adult and nymphs on the different maturation stages of longan trees. The results show that, on the none-harvested longan trees, $73.6 \%$ of total weight of the bugs were the adult bugs and $26.4 \%$ were of nymphs. In contrast, in harvested longan trees, $46.2 \%$ were adults and $53.8 \%$ were nymphs. Thus, on the none-harvested longans, production of mature longan stink bug is higher whereas production of nymph is higher in none-harvested longans. Since the data used for this analysis were collected in May, the proportion of adult and nymphs may be varied depending on the seasons of collection of the bugs.

\subsection{Estimation of production of the longan stink bug can be harvested for food in Son La province}

Based on the data in Table 2 and Table 3, the production of longan stink bug in Son La province could be estimated (Table 4).

Table 4. Total amount of the longan stink bugs estimated to be available in Son La province

\begin{tabular}{|c|c|c|c|c|c|}
\hline \multirow[t]{2}{*}{ Districts } & \multicolumn{2}{|c|}{ Number of trees } & \multicolumn{2}{|c|}{ Amount of bugs (g) } & \multirow[t]{2}{*}{ Total amount } \\
\hline & None- harvested & Harvested & None- harvested & Harvested & \\
\hline TP Son La & 0 & 11,560 & 0 & 86,700 & 86,700 \\
\hline Quynh Nhai & 34,200 & 35,400 & 23,085 & 273,642 & 296,727 \\
\hline Thuan Chau & 5,400 & 37,800 & 3,105 & 255,528 & 258,633 \\
\hline Muong La & 7,200 & 140,000 & 4,500 & 891,800 & 896,300 \\
\hline Bac Yen & 35,800 & 66,600 & 22,375 & 466,200 & 488,575 \\
\hline Phu Yen & 32,200 & 178,400 & 25,760 & $1,903,528$ & $1,929,288$ \\
\hline Moc Chau & 1,000 & 64,200 & 625 & 399,324 & 399,949 \\
\hline Yen Chau & 2,800 & 99,200 & 1,750 & 550,560 & 552,310 \\
\hline Mai Son & 0 & 263,000 & 0 & $2,740,460$ & $2,740,460$ \\
\hline Song Ma & 9,000 & 950,000 & 8,550 & $10,944,000$ & $10,952,550$ \\
\hline Sop Cop & 400 & 21,800 & 220 & 111,616 & 111,836 \\
\hline Total & 128,000 & $1,867,960$ & 89,970 & $18,623,358$ & $18,713,328$ \\
\hline
\end{tabular}

The data in Table 4 shows that, in estimation, nearly 19 tons of the longan stink bugs are available from longan tree populations. Only a small portion of this has been used by local people for food.

\subsection{The ways of consuming longan stink bugs in Son La}

Traditional ways of collecting longan stink bugs
People in Son La Province use bamboo racket, or plastic bags attached to a long handle as a trap to catch the longan stink bugs. The net or bag is placed on the top of young bud, flowers, or berries followed by shaking to let longan stink bugs falling into the racket or bags. Alternatively, people shake longan branches vigorously to detatch young longan stink bugs to fall down to the ground to catch. People also place a piece of cloth soaked with sour fermented bamboo fluid on the longan branch to fore the longan stink bugs to drop down to the ground. 


\section{Processing longan stink bugs as food}

There are different ways to Processing of the longan stink bug for food is different among different people. Kinh people usually use warm lime water of about $40-50^{\circ} \mathrm{C}$, whereas Muong and Thai people dissolved salt in fish sources and pour onto the insects. These treatments make insect secrete stinky substance from the inside of the body. Insects were then separated from liquids, and their legs and wings are removed and washed to remove completely the white layer attached to the stomach, and then dried. The unpleasant smell still remains after these steps. The unpleasant smell will disappear however, as soon as the insects were cooked, because the organic substances, which generate odor, will be degraded by heat (Figure 1,2).
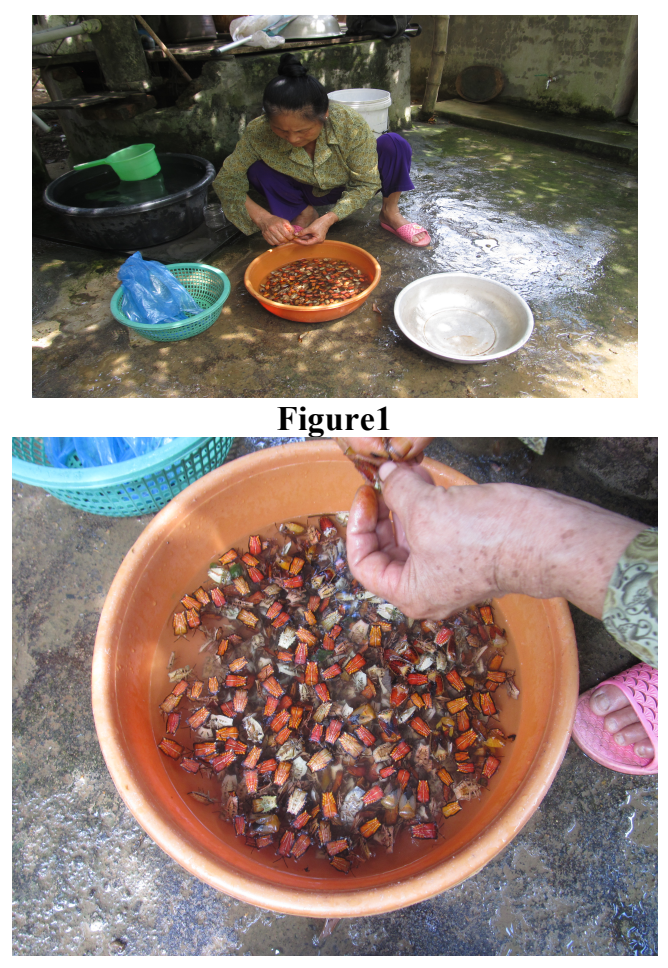

Figure 1, 2. A people in Son La processing the longan stink bug (Tessaratoma papillosa)

People fried in the pan containing hot fat, with continuous stirring until the longan stink bug turn golden, then add a little amount of fish sauce, salt as needed. The lime leaves were cut into small pieces and spread over the dish. Insect dishes offer crispy, pleasant smell, and with surprised taste. Not only as a food, people in the town of Phu Yen believe that the longan stink bugs could be used as a medicine to treat stomach ache and bleeding, to cure a sore throat and help digestion.

At the moment, longan stink bugs are mainly consumed locally as a natural food supplement within families but not much commercialized. There are only few restaurants in the Phu Yen town, Bac Yen district, and along $6^{\text {th }}$ - national road in Mai Son town, Yen Chau district, serving dishes made of the longan stink bug as a local specialty. In these places, alive longan stink bugs can be purchased at 200,000 to $250,000 \mathrm{VND} / \mathrm{kg}$.

\section{Conclusion}

- In Son La Province, D. longan is the most important fruit tree with over 10,500 ha of cultivation.

- Longan stink bug is a major pest on the longan trees in Son La province. Nymph and adult longan stink bugs suck nutrients from longan trees resulting in a reduction of growth and development of the plants, as well as reduction of the yields and quality of fruits. Since local people have a long history of traditional consumption of longan stink bugs as a natural supplement food to improve their daily meals, and the bugs are becoming a commercialized goods, increase of longan stink bug consumption could contribute to increase of longan production and improve local income and the lives of local people.

- With 10,500 ha of longan planted areas, over 18,000 kg of longan stink bugs are estimated to be harvested for use as food. In addition, the longan stink bug can also be used as a medicine to cure the diseases such as stomach ache and bleeding, help digestion and cure sore throat.

\section{Acknowledgements}

This study was supported by the Science Foundation of Vietnam Academy of Science and Technology for the project "Investigate on insect resources diversity in the Northwest, propose solutions for the development, exploitation and sustainable use"; Code VAST04.02/2014-2015.

\section{References}

[1] Allotey, J. and Mpuchane, S. ,2003. Utilization of useful insects as food source. African Journal of Food, Agriculture, Nutrition and Development 3, 1-8.

[2] Anand, H., Ganguly, A. and Haldou, P., 2008. Potential value of acridids as high protein supplement for poultry feed. International Journal of Poultry Science 7, $722-725$.

[3] Ayieko, M. A. and Oriaro, V., 2008. Consumption, indigenous knowledge and cultural values of the lake fly species within the Lake Victoria region. African Journal of Environmental Science and Technology 2, 282-286.

[4] Birgit, A.R., Oliver, K.S., 2013. Potential and challenges of insects as an innovative source for food and feed production. Innovative food Science and Emerging Technologies 17, 1-11.

[5] Bukkens, S. G. F., 1997. The nutritional value of edible insects. Ecology of Food and Nutrition 36, 287319.

[6] Cerda, H., Martinez, R., Briceno, N., Pizzoferrato, L., Manzi, P., Tommaseo Ponzetta, M., Martin, O. and Paoletti, M. G., 2001. Palm worm (Rhynchophorus palmarum), traditional food in Amazonas, Venezuela: nutritional composition, small scale production and tourist palatability. Ecology of Food and Nutrition 40, 13-32.

[7] Cerritosa, R. and Cano-Santana, C., 2008. Harvesting grasshoppers, Sphenarium purpurascens in Mexico 
for human consumption: a comparison with insecticidal control for managing pest outbreaks. Crop Protection $27,473-480$.

[8] Charnley, S., Fischer, A. P., and Jones, E. T., 2007. Integrating traditional and local ecological knowledge into forest biodiversity conservation in the Pacific Northwest. Forest Ecology and Management 246, 14-28.

[9] Chen, X., Feng, Y. and Chen, Z., 2009. Common edible insects and their utilization in China. Entomological Research 39, 299-303.

[10] Chung, A. Y. C., Chey, V. K., Unchi, S.K, Tinge, S. and Won, A., 2001. A survey of traditional use of insects and insect products as medicine in Sabah. Malaysian Naturalist 55, 24-29.

[11] DeFoliart, G. R., 1999. Insects as food: why the western attitude is important. Annual Review of Entomology 44, 21-50.

[12] DeFoliart, G. R., 2005. Overview of role of edible insects in preserving biodiversity. In Ecological Implications of Minilivestock: Potential of Insects, Rodents, Frogs and Snails. Science Publishers Inc., Enfield, NH. pp. 123-140

[13] Dreon, A.L., Paoletti, M.G., 2009. The wild food (plants and insects) in western Friuli local knowledge
(Friuli-Venezia Giulia, North Eastern Italy). Contributions to Natural History, 12, 461- 488.

[14] Edwards, J. S., 1998. Cooking of honey bee brood in East Java. Honey Bee Science 19, 149-154.

[15] Nguyen Cong Tieu, 1928. Note sur les insects comestibles au Tonkin, Bull. Econ. Indochine. Tr : 735-744.

[16] Yen, A. L., 2009a. Edible insects: traditional knowledge or western phobia? Entomological Research 39, 289-298.

[17] Yhoung-aree, J., Puwastien, P. P. and Attig, G. A., 1997. Edible insects in Thailand: an unconventional protein source? Ecology of Food and Nutrition 36, 133-149.

[18] Vietnam National University, Institute of Ecology and Biological Resources (2005). A list of all plant species in Vietnam, Volume 3, Agricultural Publishing House.

[19] Forest Inventory and Planning Institute, Northwest (2009). Report on the survey, assessment of the situation and developmental investment opportunities on forestry of Northwest region. General Report of Project Performance.

[20] Son La Provincial People's Committee (2014). Statistical Yearbook 2013. 